\title{
A HYBRID MODEL OF SOLAR-WIND - BIOMASS POWER GENERATION SYSTEM
}

\author{
Rahul Sharma ${ }^{(1)}$, Varinder Goyal ${ }^{(2)}$ \\ ${ }^{(1)}$ Research Scholar, Department of Electrical Engineering, GTBKIET, Malout \\ lect.rahulsharma@gmail.com \\ (2) Assistant Professor, Department of Electrical Engineering, GTBKIET, Malout \\ goyal.varinder@gmail.com
}

\section{ABSTRACT}

Renewable energy technologies offer the promise of clean, abundant energy gathered from self-renewing resources such as the sun, wind, water, earth, and plants. In this thesis a detailed modeling of hybrid power generation system of solar, wind and biomass has been developed in Matlab. The simulation includes all realistic components of the system. In this thesis, the power delivered by the combine system component is compared with each other and various conclusions are drawn. The various advantages and disadvantages of the system are compared, and a cost analysis of the system is carried on with the present system.

\section{Keywords}

Renewable Energy : Solar Energy, Wind Energy, Biomass Energy.

\section{Council for Innovative Research}

Peer Review Research Publishing System

Journal: International Journal of Research in Education methodology

Vol. 7, No.2

ijremeditor@gmail.com

www.jirem.com 


\section{INTRODUCTION}

Virtually all regions of the world have renewable resources of one type or another[1]. Renewable energy technologies offer important benefits compared to those of conventional energy sources. Worldwide, 1000 times more energy reaches the surface of the earth from the sun than is released today by all fossil fuels consumed. Photovoltaic's and wind generation are also an attractive source of energy because of their benign effect on the environment. Increased population growth and economic development are accelerating the rate at which energy and in particular electrical energy is being demanded. All methods of electricity generation have consequences for the environment, so meeting this growth in demand, while safeguarding the environment poses a growing challenge.

Each of the renewable energy technologies is in a different stage of research, development, Commercialization and all have differences in current and future expected costs, current industrial base, resource availability, and potential impact on greenhouse gas emissions. Hybrid power systems consist of a combination of renewable energy sources such as: photovoltaic (PV), wind generators, etc., to charge batteries and provide power to meet the energy demand, considering the local geography and other details of the place of installation. These types of systems, which are not connected to the main utility grid, are also used in stand-alone applications and operate independently and reliably. The best applications for these systems are in remote places, such as rural villages, in telecommunications, etc.

\section{A. SOLAR ENERGY}

Energy supplied by the sun in one hour is almost equal to the amount of energy required by the human population in one year. Renewable energy sources play an important role in electricity generation.[2] Various renewable energy sources like wind, solar, geothermal, ocean thermal, and biomass can be used for generation of electricity and for meeting our daily energy needs. Energy from the sun is the best option for electricity generation as it is available everywhere and is free to harness. On an average the sunshine hour in India is about $6 \mathrm{hrs}$ annually also the sun shine shines in India for about 9 months in a year. Electricity from the sun can be generated through the solar photovoltaic modules (SPV). Solar Energy is a good choice for electric power generation. The photovoltaic modules are made up of silicon cells. The silicon solar cells which give output voltage of around $0.7 \mathrm{~V}$ under open circuit condition. When many such cells are connected in series we get a solar PV module. Normally in a module there are 36 cells which amount for a open circuit voltage of about $20 \mathrm{~V}$. The current rating of the modules depends on the area of the individual cells. Higher the cell area high is the current output of the cell.[3] For obtaining higher power output the solar PV modules are connected in series and parallel combinations forming solar PV arrays. A simplest model of power generation through solar energy is shown in Figure 1.

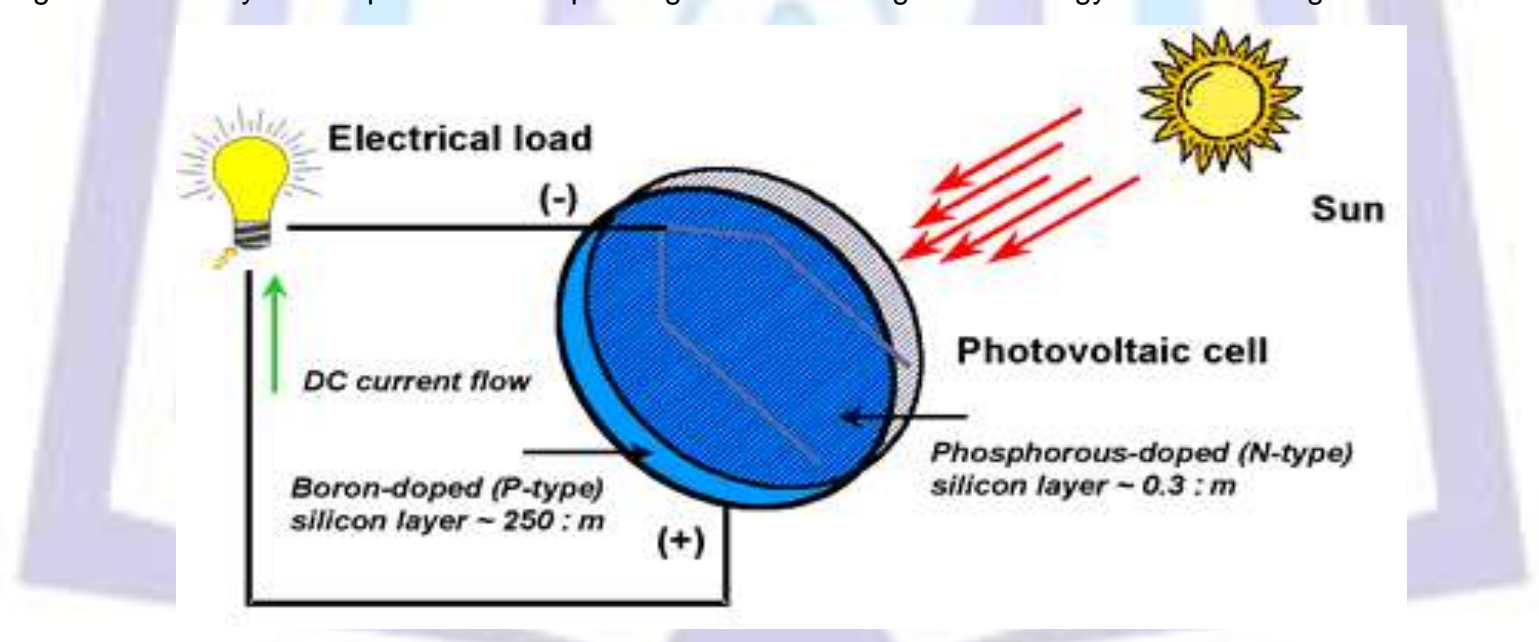

Figure-1 How solar cells Generate electricity

Power output from the PV array can be obtained by using the equation

Ppv $(t)=\operatorname{lns}(t) * A^{*}$ Efficiency of Photovoltaic

Where INS $(\mathrm{t})=$ isolation data at time $\mathrm{t}(\mathrm{kw} / \mathrm{m} 2)$

$A=$ area of single $P V$ panel $(\mathrm{m} 2)$

Efficiency of Photovoltaic $=$ overall efficiency of the PV panels and dc $/ \mathrm{dc}$ converters 


\section{B. WIND ENERGY}

Wind power systems convert the kinetic energy of the wind into other forms of energy such as electricity. Although wind energy conversion is relatively simple in concept, turbine design can be quite complex. Most commercially available wind turbine uses a horizontal - axis configuration with two or three blades, a drive train including a gearbox and a generator and a tower to support the rotor. Typical sizes for a wind turbine range from 200-750 KW, and electricity produce within a specific range of wind speed. Capital costs have declined from about $\$ 2.2 / \mathrm{w}$ in early 1980 to less than $\$ 1 / \mathrm{w}$ today. Cooperative research between DOE and manufacturing companies is aimed at increasing the aerodynamics efficiency and structural strength of wind turbine blades, developing variable speed generation and electronic power controls and using taller tower that allow access to the stronger wind found at greater height.

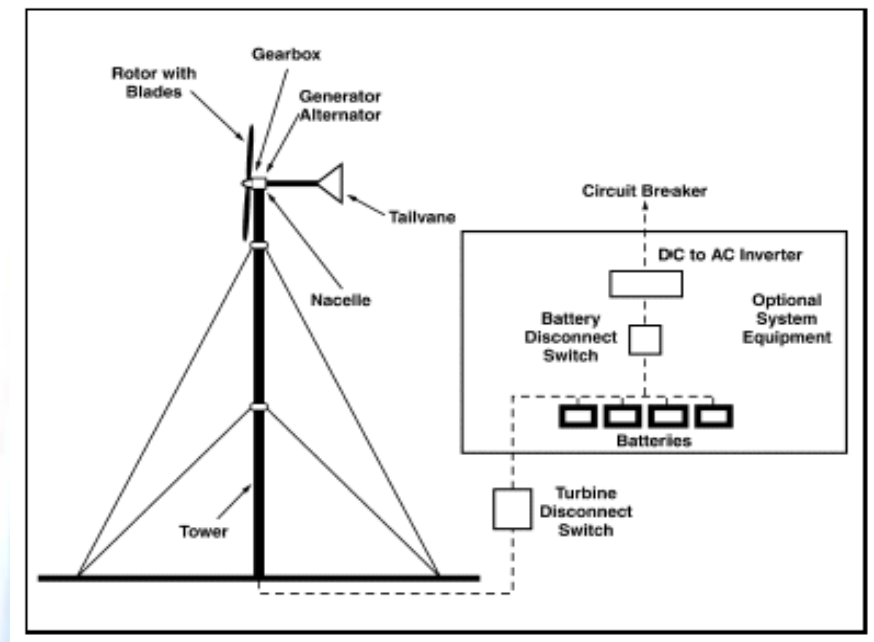

Figure - 2 Components of a wind energy system.

In wind conversion system wind speed data is evaluated and converted to wind turbine power. If the speed is between cutin and the rated speed of the wind turbine, then the power output is defined as:

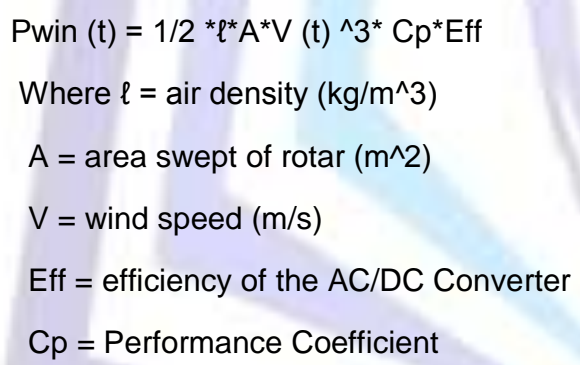

If the wind speed is between the rated wind speed and the furling speed of the wind turbine, the power output will be equal to the rated power of the turbine and if the wind speed is less than the cut-in speed or greater than the furling speed there will be no power output from the turbine.

\section{BIOMASS ENERGY}

To many people, the most familiar forms of renewable energy are the wind and the sun. But biomass (plant material and animal waste) is the oldest source of renewable energy, used since our ancestors learned the secret of fire. Until recently, biomass supplied far more renewable electricity—or "biopower"-than wind and solar power combined. If developed properly, biomass can and should supply increasing amounts of biopower sustainable, low-carbon biomass can provide a significant fraction of the new renewable energy we need to reduce our emissions of heat-trapping gases like carbon dioxide to levels that scientists say will avoid the worst impacts of global warming. Without sustainable, low-carbon biopower, it will likely be more expensive and take longer to transform to a clean energy economy.

But like all our energy sources, biopower has environmental risks that need to be mitigated. If not managed carefully, biomass for energy can be harvested at unsustainable rates, damage ecosystems, produce harmful air pollution, consume large amounts of water, and produce net greenhouse emissions.

However, most scientists believe there is a wide range of biomass resources that can be produced sustainably and with minimal harm, while reducing the overall impacts and risks of our current energy system. Implementing proper policy is essential to securing the benefits of biomass and avoiding its risks. 
Biomass is a renewable energy source not only because the energy it comes from the sun, but also because biomass can re-grow over a relatively short period of time. Through the process of photosynthesis, chlorophyll in plants captures the sun's energy by converting carbon dioxide from the air and water from the ground into carbohydrates-complex compounds composed of carbon, hydrogen, and oxygen.

\section{Direct Combustion / Steam Turbine System}

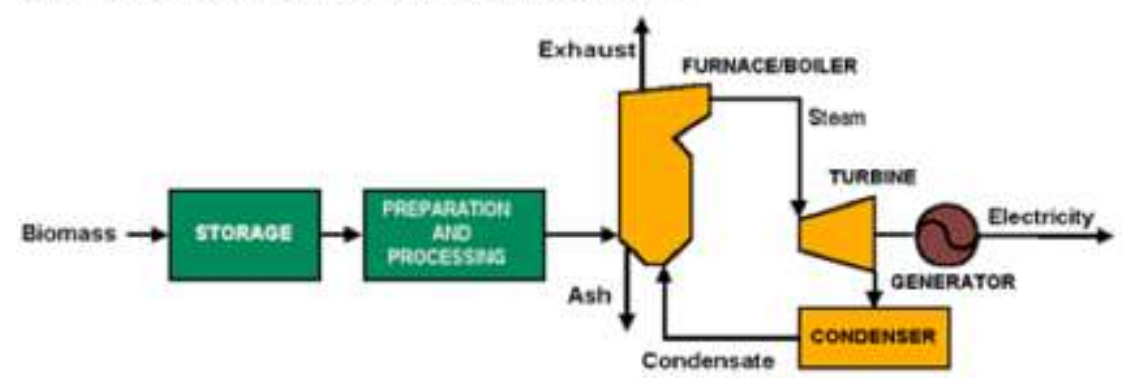

Figure -3 Working of a typical biomass plant

\section{IMPLEMENTATION}

A Simple Model of PV Mind/ Biomass system is shown in figure 4. This model consist of PV arrays, Wind turbine and biomass plant combine to work as Hybrid model which uses batteries for its storage. The detail modeling of this model is divided in four parts modeling of PV Module, modeling of Wind Turbine, modeling of Batteries and modeling of biomass plant.

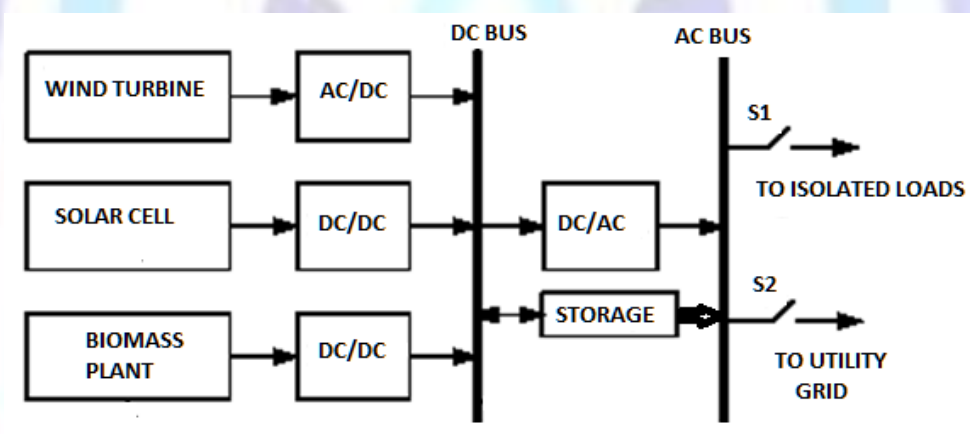

Figure - 4 A Simple Model of PV Mind/ Biomass system

\section{Simulation of PV Module}

The I- V characteristic of the PV module are :

$$
\begin{aligned}
& I=I L-I 0\left(e^{\wedge} q(V+I R S) / n k T_{-} 1\right) \\
& \text { Where IL = photo current } \\
& I 0=\text { diode saturation current } \\
& \mathrm{RS}=\text { series current } \\
& \mathrm{q}=\text { charge of electron } \\
& \mathrm{k}=\text { constant } \\
& \mathrm{T}=\text { temperature } \\
& \mathrm{N}=\text { number of PV module }
\end{aligned}
$$




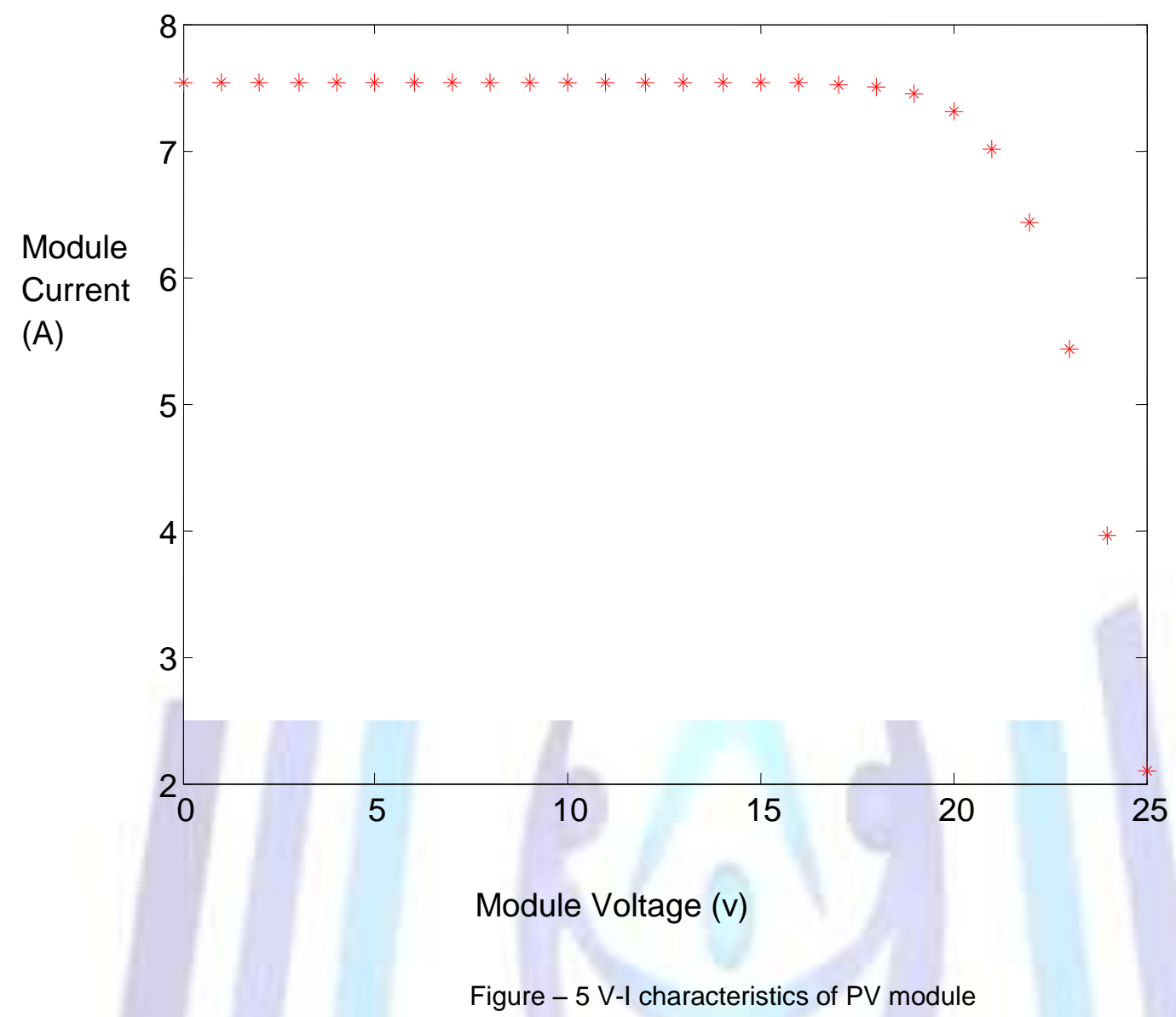

\section{Simulation of Wind Turbine:}

As we know that power delivered by a wind turbine is given by

Pwin $(t)=1 / 2 * \ell^{\star} A^{*} V(t) \wedge 3^{*} C p^{*} E f f a d$

Where $\ell=$ air density $\left(\mathrm{kg} / \mathrm{m}^{\wedge} 3\right)$

$A=$ area swept of rotar $\left(m^{\wedge} 2\right)$

$\mathrm{V}=$ wind speed $(\mathrm{m} / \mathrm{s})$

Effad $=\quad$ efficiency of the AC/DC Converter 


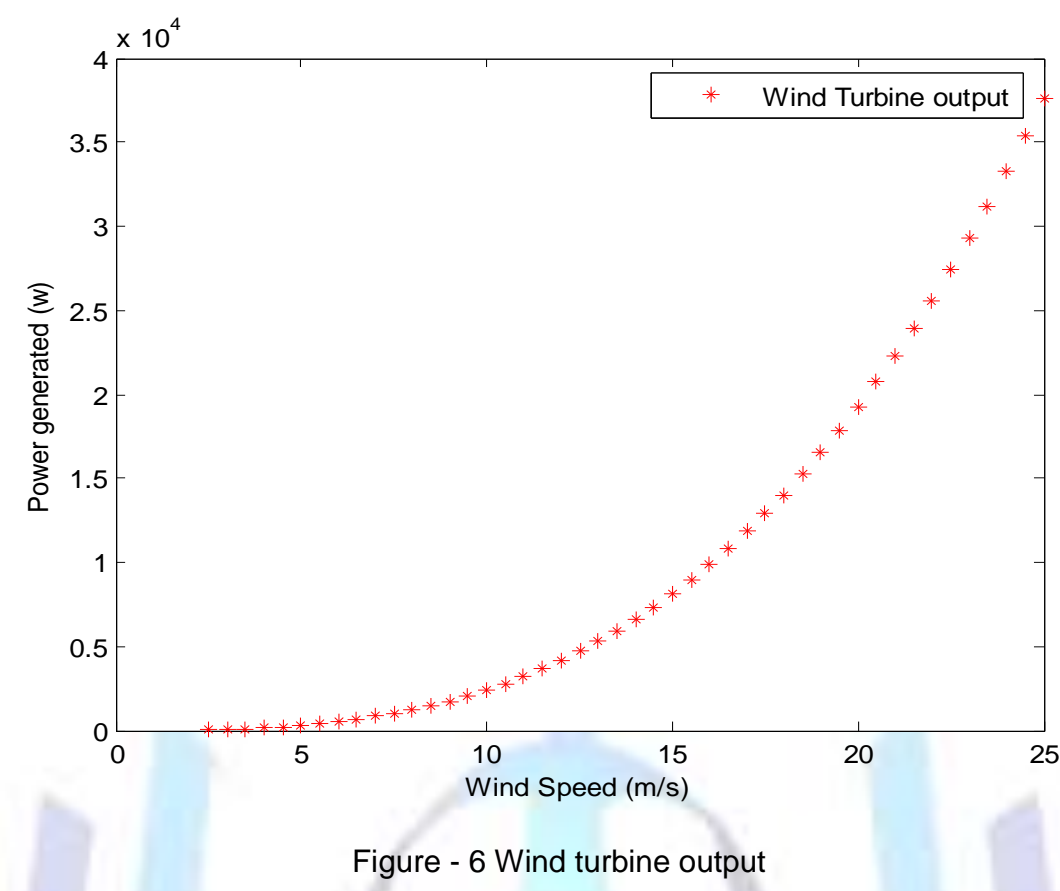

Power is directly proportional to wind speed, as the wind speed increases the power delivered by a wind turbine also increases as shown in figure 23. If wind speed is between the rated wind speed and the furling speed of the wind turbine, the power output will be equal to the rated power of the turbine. Finally, if the wind speed is less than the cut-in speed or greater than the furling speed there will be no output power from the turbine.

The cut in speed and the rated speed for a wind turbine varies with the type of wind turbine we are using, in our case $A$ Bergey BWC XL.11 kW wind turbine was selected because it gave good performance and lowest cost, the parameters of the wind turbine are shown in table 1

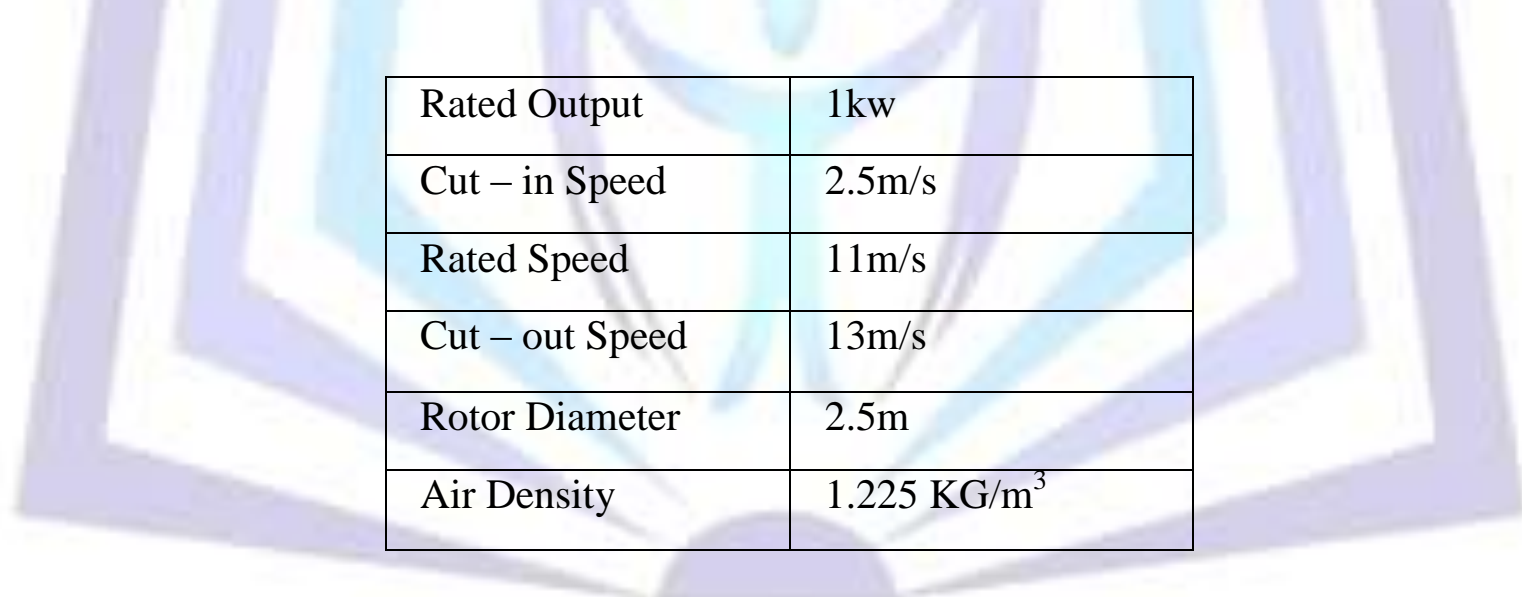

Table - 1 The parameters of the wind turbine

Now if the wind speed is between $2.5 \mathrm{~m} / \mathrm{s}$ and $11 \mathrm{~m} / \mathrm{s}$ the power will be delivered by the wind turbine, it has been seen that if the wind sped is between $9 \mathrm{~m} / \mathrm{s}$ to $11 \mathrm{~m} / \mathrm{s}$ the output will be approximately equal to $1 \mathrm{KW}$, which is our desired values. Now plotting the curve for various values of $\mathrm{Cp}$. Power generated by a wind turbine for different value of $\mathrm{Cp}$ is shown in figure 7. 


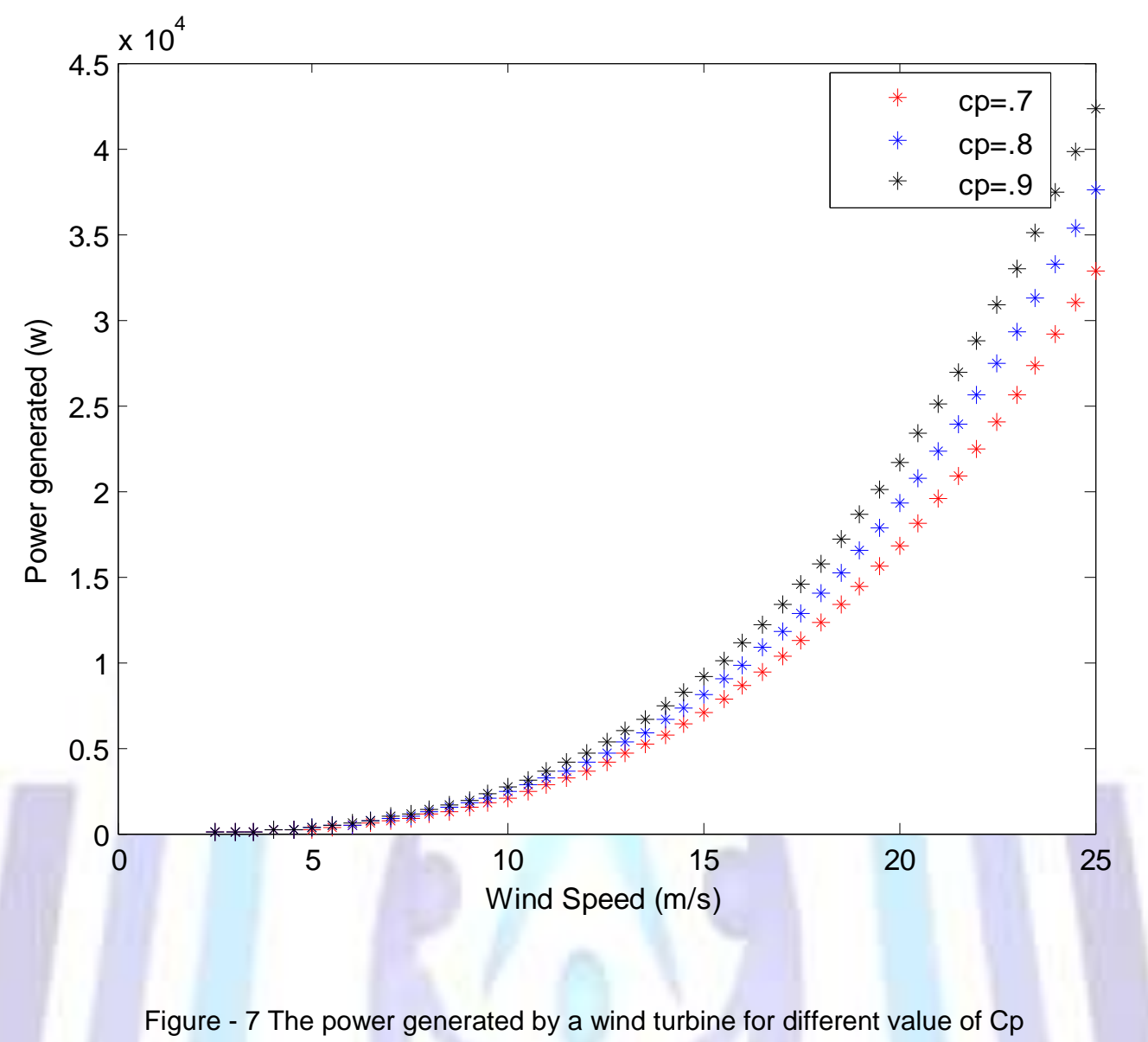

\section{Simulation of Biomass}

Gross Calorific Value of Biomass $=20 \mathrm{MJ} / \mathrm{Kg}$

Average Efficiency of Biomass Plant $n=.25$ (25\%)

And we all know that $3.6 \mathrm{MJ}=1 \mathrm{KW}$

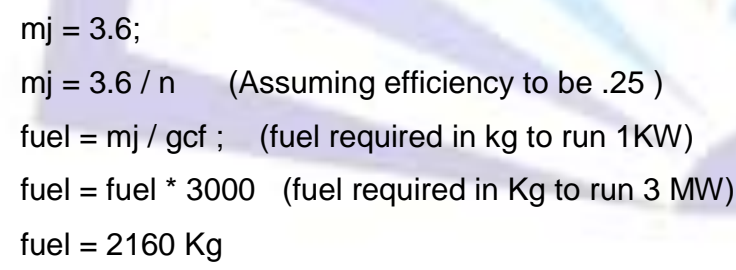




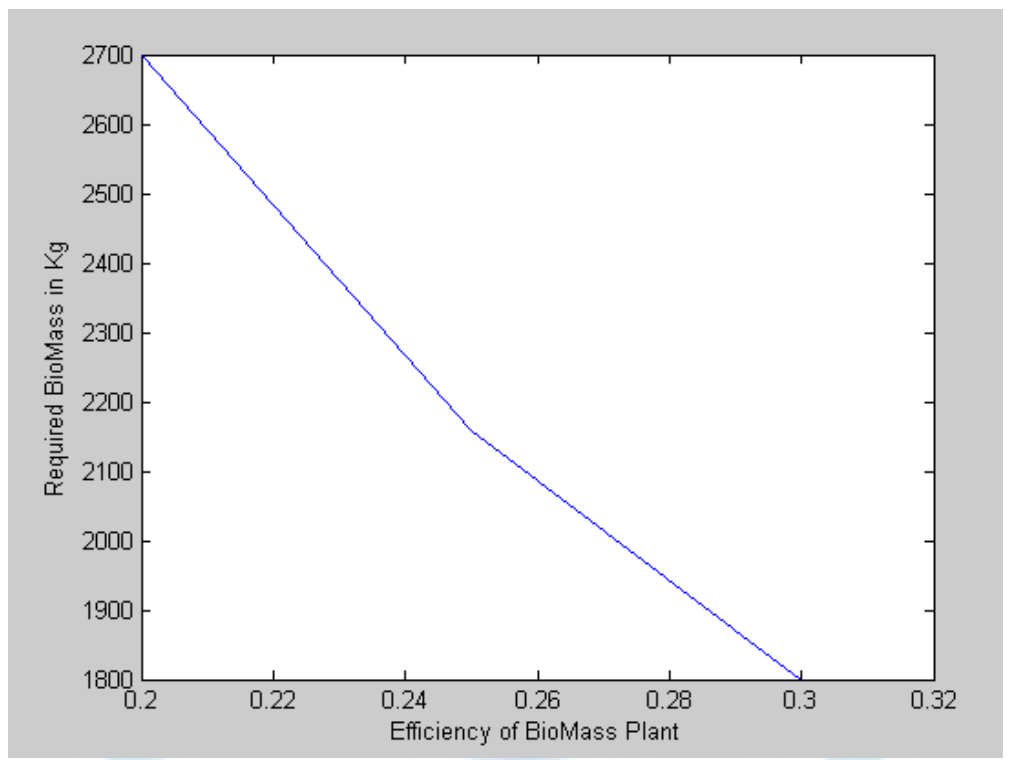

Figure - 8 Graph of Biomass Required vs Efficiency of Biomass Plant

\begin{tabular}{|c|c|c|c|}
\hline TYPE & RATE (PER UNIT IN RS.) & UNITS & COST (IN Rs.) \\
\hline BIOMASS & 4 & 500 & 2000 \\
\hline SOLAR & 8 & 500 & 4000 \\
\hline WIND & 3.70 & 500 & 1850 \\
\hline CURRENT & 7 & 500 & 3500 \\
\hline HYBRID & 5.23 & 500 & 2615 \\
\hline
\end{tabular}

Table - 2 COST ANALYSIS OF DIFFERENT ENERGY SOURCES

It is clear that the cost per unit of a hybrid model of PV/WIND/BIOMASS CELL is lower than the currently existing model. 


\section{CONCLUSION}

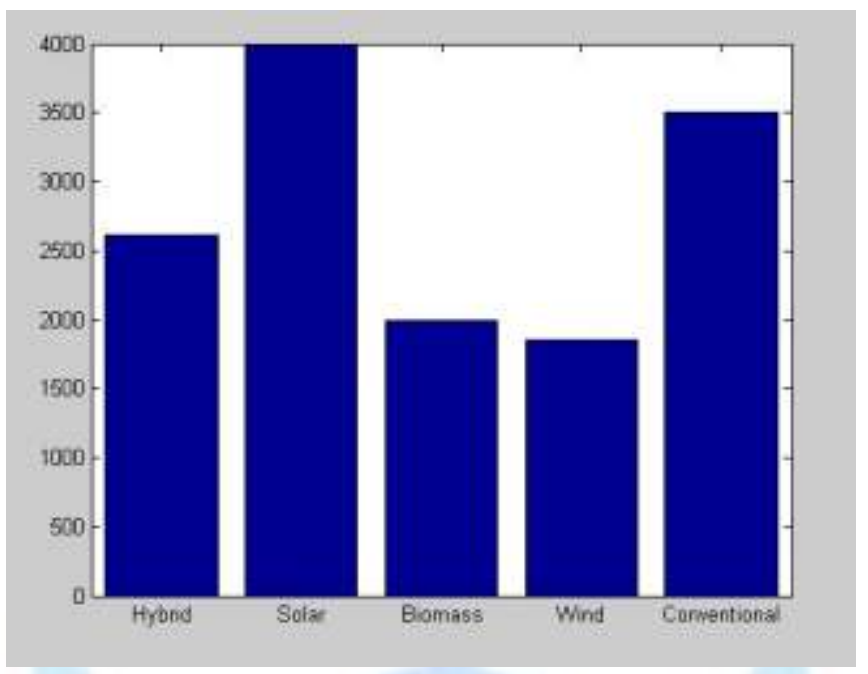

In this thesis work, a hybrid model of PV/Wind/biomass energy system is developed. We have also seen that this model is more effective and more reliable as compared to the earlier one. The power delivered by hybrid model of PV/WIND/BIOMASS is much higher and economical than the current system. The system is more environmental friendly and the waste products of this system do not contain any harmful gases/products, this model use all the renewable energy sources for electric generations which are the need of the time. With the use of energy from wind, solar, biomass it will help to reduce our dependency on fossil fuels. The result shows by the experimental and theoretical data that has been able to predict the energy generation through hybrid system. This method motivates the engineers to install small scale hybrid system in the country. The government of India is taking a major decision towards the hybrid energy sources. While implementing the system; the cost of the land, the cost of setting up the complete infrastructure and operating it should also be taken into account.

\section{REFERENCES}

[1] A. Traca de Almedia, A. Martins, H. Jesus \& J. Climaco, "Source Reliability in a Combined Wind - Solar - Hydro System", IEEE Transactions on Power Apparatus and System, Vol. PAS - 102, No. 6, June 1983.

[2] Caisheng Wqang , M.Hashem Nehrir ," Economics of a grid -Connected solar Cells." IEEE Transactions on Power Delivery, Vol.15, No.1, pp.350-354. June 2001.

[3] C.Wang, M.H. Nehrir and H.Gao, "Control of Solar Cell Distributed Generation Systems." IEEE Transactions CONVERSION ,VOL.21,JUNE 2006

[4] C.R. Bordallo1, C.Garcial, J.Bery1, J.M Maza2, "Dynamic model and simulations of a PEM solar cell for residential applications." Proceedings of the IEEE, Vol. 19, No. 2Jan 2008.

[5] D.B. Nelson, M.H. Nehrir and C. Wang, "Unit Sizing of Stand - Alone Hybrid Wind/PV Power Generation System". Proceedings of the IEEE, Vol. 66, No.5 Apr 2002.

[6] Dr. Recayi Pecen, Dr. MD Salim \& Ayhan Zora, "A Lab View Based Instrument System for a Wind-solar Hybrid Power Station," Vol 20, No-3 June 2004 through August 2004.

[7] Dr. Recayi Pecen, Dr. MD Salims, Dr. Marc Timmerman, “ A Hybrid Solar-wind Power Generation System as an Instructional Resource for Industrial Technology Students”, Vol. 16, No. 3, May 2000 to July 2000.

[8] D.B Nelson and M.H Nehrir , "Economics of Grid -ConnectedCell." Proceedings of the IEEE, Vol. 21, No. 8 August 2002. 
[9] Hongxing Yang, Wei Zhou , Lin Lu , Zhaohong Fang "Optimal sizing method for stand-alone hybrid solar-wind system with LPSP technology by using genetic algorithm" Science Direct Transaction on Solar Energy, Vol. 82, 354-367, August 2007.

[10] Jozef Paska, Piot \& Biczel, Mariusz Klos, "Experience with Hybrid Power Generating System". Proceedings of the IEEE, Vol. 21, No. 4 July 2009.

[11] J. Bhagwan Reddey, D.N. Reddy "Probablistic Performance Assessment of a Roof Top Wind, Solar Photo Voltaic Hybrid Energy System". Proceedings of the IEEE, Vol. 99, No. 12 August 2011.

[12] Jin Wang, Fang Z. Peng, Joel Anderson, Alan Joseph and Ryan Buffen Barger, "Low System for Residential Power Generation". IEEE Transaction on Power Electronics, Vo. 19, No. 5, Sept. 2004.

[13] J.G.Slootweg ,S.W.H .de Haan 2h Polinder W.L.Kling , "Modeling Wind Turbine in Power System Dynamics Simulations." IEEE Transactions on Power Systems, Vol.6, No.1,307-316. May 1991

[14] J.A. Smith M.H.Nehrir, V.Gerez and S.R. SHAW, "A Broad Look at the workings, Types and Applications of Fuel cells.".

[15] J.Bhagwan Reddy, D.N. Reddy, "Modeling of Wind Turbine for Power System Studies." VOL.17,NO.4,NOVEMBER 2002.

[16] Kourash Sedghisigarchi \& Ali Fellachi, "Impact of Fuel Cells on Load - Frequency Control in Power Distribution Systems”, IEEE Transaction of Energy Conversion Vol. 21, No.1, March 2006. 